\title{
Analisis Dampak Penggunaan Varian Tekanan Suction terhadap Pasien Cedera Kepala Berat
}

\author{
Hendy Lesmana ${ }^{1}$, Tri Wahyu Murni ${ }^{2}$, Anastasia Anna ${ }^{3}$ \\ ${ }^{1}$ Fakultas Ilmu Kesehatan, Universitas Borneo, ${ }^{2}$ Fakultas Kedokteran, Universitas Padjadjaran, ${ }^{3} \mathrm{Fakultas}$ \\ Keperawatan, Universitas Padjadjaran \\ E-mail : hendylesmana2@gmail.com
}

\begin{abstract}
Abstrak
Penurunan kesadaran pada pasien cedera kepala berat akan menimbulkan risiko gangguan jalan napas sehingga perlu dilakukan intubasi endotrakeal untuk mempertahankan perfusi otak. Suctioning diperlukan untuk mempertahankan oksigenasi tetapi dapat menimbulkan penurunan saturasi oskigen, peningkatan TIK dan trauma jalan nafas. Tekanan suction yang tepat sangat diperlukan untuk mengatasi penurunan saturasi oksigen pada klien cedera kepala berat. Penelitian Quasi experiment ini bertujuan mengetahui perbedaan saturasi oksigen pada pasien cedera kepala setelah dilakukansuctioning pada tekanan $100 \mathrm{mmHg}, 120 \mathrm{mmHg}$ dan $150 \mathrm{mmHg}$. Desain penelitian menggunakanone group pretest and post testwithout control, yang dilakukan pengukuran berulang. Hasil penelitian didapatkan semakin tinggi penggunaan tekanan suction maka akan semakin terjadi penurunan saturasi oksigen. Hasil penelitian ini diharapkan menjadi panduan dalam melakukan suction pada pasien cedera kepala berat dengan memerhatikan saturasi oksigen.
\end{abstract}

Kata kunci: Cedera kepala berat, hiperoksigenasi, suctioning, saturasi oksigen, \& tekanan suction.

\section{The Use of Different Pressure of Suction and Its Impact on Oxygen Saturation among Patients with Head Injury}

\begin{abstract}
Rather maintaining adequate airway patency, suctioning may pose risk of developing diminished oxygen saturation among patient with severe head injury. Patients may also experience intra cranial pressure (ICP) and airway trauma. Therefore, providing appropriate pressure of suction machine is needed to overcome those problems particularly to reduce risk of diminished oxygen saturation. This quasi-experimental study aimed to determine differences in oxygen saturation among patients with head injury after suctioning with three different pressures: $100 \mathrm{mmHg}, 120 \mathrm{mmHg}$ and $150 \mathrm{mmHg}$. The study design used one group pretest and post-test without control that performed with repeated measurements. Findings suggest higher pressure of suctioning tends to decrease their oxygen saturation. Results are expected to provide best practice to conduct suctioning for patients with severe head injury and maintaining oxygen saturation after hyper oxygenation action.
\end{abstract}

Key words: Hyperventilation, oxygen saturation, severe head injury, suctioning, and suction pressure. 
Hendy Lesmana: Analisis Dampak Penggunaan Varian Tekanan Suction

\section{Pendahuluan}

Menurut Henderson yang dikutip oleh Basfort dan Slevin (2006), perawat harus selalu meyakini bahwa terdapat kebutuhan pasien yang harus dipenuhi oleh perawat. Karakteristik utama dari sakit dimana pasien mengalami ketergantungan pada berbagai tingkat inkapasitas individu sehingga fungsi perawat adalah memenuhi kebutuhan dasar dari pasien dimana kebutuhan oksigenasi merupakan kebutuhan yang sangat vital bagi pasien terutama pada pasien yang mengalami penurunan kesadaran.

Pasien yang mengalami penurunan kesadaran umumnya mengalami gangguan jalan nafas, gangguan pernafasan dan gangguan sirkulasi. Gangguan pernafasan biasanya disebabkan oleh gangguan sentral akibat depresi pernafasan pada lesi di medula oblongata atau akibat gangguan perifer, seperti : aspirasi, edema paru, emboli paru yang dapat berakibat hipoksia dan hiperkapnia. Tindakan yang dapat dilakukan pada kondisi di atas adalah pemberian oksigen, cari dan atasi faktor penyebab serta pemasangan ventilator. Pada pasien cedera kepala berat dan sudah terjadi disfungsi pernafasan, di rawat di ruang perawatan intensif dan terpasang selang endotrakheal dengan ventilator dan sampai kondisi klien menjadi stabil (Muttaqin, 2008; Basuki \& Dian, 2009; Hudak \& Gallo, 2010).

Pasien yang terpasang ventilator membutuhkan rencana keperawatan yang khusus. Perawatan jalan nafas terdiri dari pelembapan adekuat, tindakan membuang sekret, perubahan posisi dan suctioning. Kelembapan saluran nafas dapat dilakukan dengan menggunakan cairan humidifier, semua udara yang dialirkan dari ventilator melalui air humidifier, dihangatkan dan dijenuhkan. Tindakan ini berfungsi untuk mencegah obstruksi jalan nafas yang disebabkan oleh sekresi kering dan perlengketan mukosa. Suction dilakukan bila terdengar suara ronki atau sekresi terdengar saat pernafasan. Peningkatan tekanan inspirasi puncak pada ventilator dapat mengindikasikan adanya perlengketan atau penyempitan jalan nafas oleh sekret, juga menunjukkan kebutuhan untuk dilakukan suction (Hudak \& Gallo, 2010). Peningkatan sekresi dan kekentalan dari mukus pada pasien yang terpasang ventilator dapat menyebabkan penyumbatan pada lumen selang endotrakeal (ETT) sehingga menyebabkan pasien kritis mengalami masalah pada status respirasinya. Tindakan keperawatan dibutuhkan segera untuk mengeluarkan sekret dari jalan nafas dengan suctioning atau pembersihan pada lumen ETT (Stone et al, 1998).

Pengisapan (suction) adalah aspirasi sekret melalui sebuah kateter yang disambungkan ke mesin pengisap atau saluran pengisap yang ada di dinding. Pengisapan dapat dilakukan melalui nasofaring, orofaring dan intubasi endotrakeal. Suction adalah tindakan keperawatan yang paling sering dan penting pada tatanan keperawatan kritis. Prosedur suctioning banyak bervariasi antar lembaga dan praktisi, hal ini dikarenakan suctioning hanya didasarkan pada kegiatan rutin perawat daripada berdasarkan hasil penelitian. Minimnya penelitian terkait suctioning menyebabkan bervariasinya suctioning antar lembaga dan praktisi kesehatan (Thompson et al., 2000 dalam Kelleher \& Andrews, 2006).

Tindakan pengisapan endotrakeal dapat menyebabkan beberapa masalah pada pasien kritis bila dilakukan dengan prosedur yang tidak benar, di antaranya penurunan saturasi oksigen, disritmia jantung, hipotensi, dan bahkan menyebabkan peningkatan tekanan intrakranial (Hudak \& Gallo, 2010). Pengaturan penggunaan tekanan suction dan pemberian hiperoksigenasi sebelum suctioning dapat meminimalkan efek samping yang terjadi. Tekanan suction yang dianjurkan adalah $100 \mathrm{mmHg}-150 \mathrm{mmHg}$, tetapi belum ada data yang menunjukkan seberapa besar penggunaan tekanan tersebut dapat menyebabkan penurunan saturasi oksigen, sehingga dibutuhkan penelitian lanjutan untuk mengkaji hal tersebut (Wainwright \& Gould, 1996).

Terdapat variasidalampenggunaan tekanan negatif pada suctioning baik pada beberapa literatur atau pun beberapa penelitian. Glass \& Grap (1995), merekomendasikan penggunaan tekanan negatif suctioning pada pasien dewasa sebesar $80 \mathrm{mmHg}$ 120 mmHg. Kozier, Berman, dan Snyder 
Hendy Lesmana: Analisis Dampak Penggunaan Varian Tekanan Suction

(2011) merekomendasikan penggunaan tekanan suction pada pasien dewasa antara $100 \mathrm{mmHg}-120 \mathrm{mmHg}$. Berman et al., (2009), merekomendasikan tekanan negatif suction pada pasien dewasa sebesar $100 \mathrm{mmHg}-120 \mathrm{mmHg}$. Hahn (2010), menganjurkan penggunaan tekanan suction pada pasien dewasa sebesar $70 \mathrm{mmHg}-150$ mmHg. Mestecky dan Woodward (2011), menganjurkan tekanan suction antara 100-150 mmHg, jika sekret kental jangan mencoba meningkatkan tekanan suction tetapi sekret yang kental dapat dimobilisasi dengan menggunakan humidifikasi dan tindakan nebulezer. Tekanan $100 \mathrm{mmHg}$ merupakan tekanan negatif minimal yang dianjurkan untuk melakukan suction tetapi tekanan suction dapat diatur berdasarkan jumlah dan karakteristik dari sekret yang terdapat pada jalan nafas, bila tekanan 100 $\mathrm{mmHg}$ belum dapat memobilisasi sekret maka tekanan dapat ditingkatkan menjadi $120 \mathrm{mmHg}$, tekanan dapat maksimal hingga $150 \mathrm{mmHg}$ karena bila lebih dari tekanan tersebut dapat menyebabkan trauma jalan nafas dan hipoksia (Potter \& Perry, 2010; Hahn, 2010; Day et al. 2002).

Berdasarkan uraian di atas, peneliti mengambil kesimpulan bahwa sangat terbatas literatur atau penelitian yang mengkaji tekanan suction yang efektif dalam mempertahankan saturasi oksigen yang adekuat untuk pasien yang dirawat di ruang intensif khususnya pasien cedera kepala berat. Dari beberapa literatur dan penelitian, tekanan negatif yang banyak dianjurkan pada suction adalah $100 \mathrm{mmHg}, 120 \mathrm{mmHg}$ dan maksimal $150 \mathrm{mmHg}$, sehingga penting untuk melakukan penelitian "analisis dampak penggunaan varian tekanan suction terhadap pasien cedera kepala berat".

\section{Metode Penelitian}

Penelitianinimerupakanpenelitiankuantitatif, dengan metode penelitian eksperimen semu (quasi experiment) khususnya menggunakan desain pre and post test without control group dengan pengukuran yang berulang (repeated measures) dengan pertimbangan ketika menggunakan satu responden yang dilakukan pengukuran berulang dapat meminimalkan variabel perancu (kondisi fisiologis paru) bila dilakukan pada responden yang berbeda.

Populasi adalah semua pasien cedera kepala berat yang terpasang selang endotrakeal di ruang Neurosurgical Critical Care Unit (NCCU) yang memenuhi kriteria inklusi yg telah ditetapkan. Teknik sampling menggunakan purposive sampling, dimana peneliti memilih sampel berdasarkan pertimbangan tertentu diantaranya kondisi klinis klien. Jumlah sampel yang ditetapkan berdasarkan hasil perhitungan rumus analitis numerik berpasangan dengan mempertimbangkan drop out sebesar $10 \%$ maka jumlah sampel ditetapkan sebanyak 21 responden.

Pengumpulan data penelitian dimulai dari Bulan April sampai dengan Juni 2013 hingga jumlah sampel mencapai 21 responden. Penelitian ini dilaksanakan di Ruang Perawatan Neurosurgical Critical Care Unit (NCCU) RSUP Dr Hasan Sadikin Bandung.

Pasien cedera kepala berat yang memenuhi kriteria inklusi penelitian sebelumnya dilakukan hiperoksigenasi 1-3 menit hingga saturasi oksigen melebihi 95\%, kemudian dilakukan suctioning dengan tekanan 100 mmhg dan dilakukan pengukuran saturasi oksigen. Ketika ada indikasi suction, kegiatan ini diulang dengan penerapan tekanan 120 $\mathrm{mmHg}$ dan $150 \mathrm{mmHg}$.

Uji normalitas data dilakukan dengan menggunakan rumus uji Shapiro Wilk. Hasil uji Shapiro Wilk menunjukkan nilai $\mathrm{p}<$ 0,05 , maka dapat disimpulkan bahwa data saturasi oksigen setelah suctioning tidak berdistribusi normal. Dengan demikian maka analisis data dilakukan dengan uji Friedman dan dilanjutkan dengan uji post-hoc : uji wilcoxon.

Dalam rangka menjunjung tinggi ethical clearance, maka peneliti memegang teguh sikap ilmiah (scientific attitude) serta menggunakan prinsip etika penelitian, yaitu: Beneficence, Non Maleficence, Autonomy, Anonimyty, Veracity dan Justice. Penelitian ini juga telah mendapatkan persetujuan etik oleh Komite Etik Penelitian Kesehatan Fakultas Kedokteran Universitas Padjadjaran Bandung dengan nomor : 160/UN6.C2.1.2/ KEPK/PN/2013. 
Hendy Lesmana: Analisis Dampak Penggunaan Varian Tekanan Suction

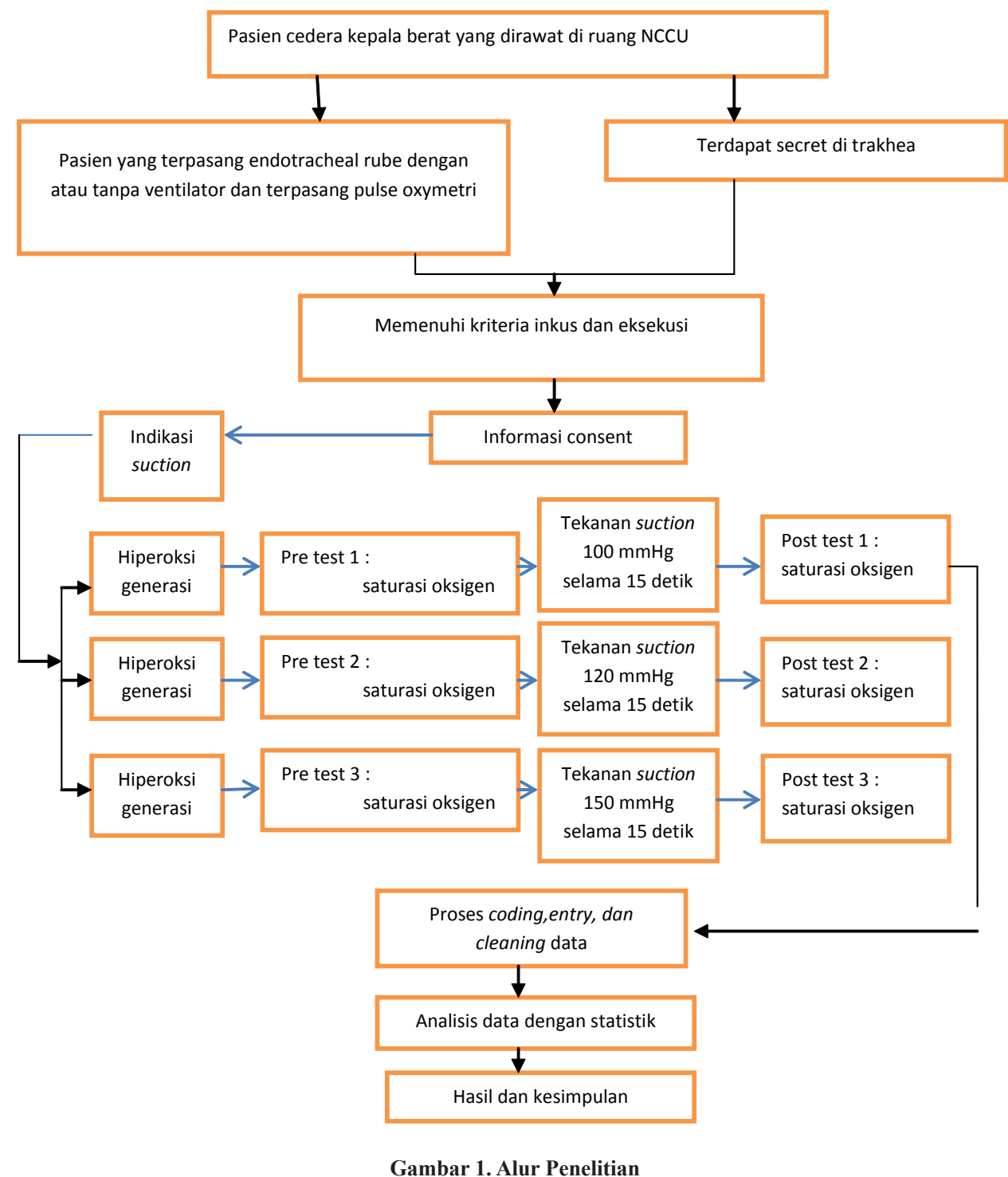

\section{Hasil Penelitian}

Sebelum dilakukan suctioning, responden sebelumnya dilakukan tindakan hiperoksigenasi terlebih dahulu guna mencegah terjadi hipoksia setelah suction dilakukan. Guna menilai homogenitas responden sebelum dilakukan tindakan suction, maka dilakukan pendokumentasian nilai saturasi sebelum suction (Tabel. 1).

Tabel 1 Nilai Saturasi Oksigen Sebelum Suctioning dengan Tekanan 100 mmHg, 120 mmHg dan 150 mmHg di Ruang NCCU 2013

\begin{tabular}{cccccc}
\hline \multirow{2}{*}{$\begin{array}{c}\text { Tekanan } \\
\text { Suction }\end{array}$} & Min & Max & Rata-Rata & SD & p Value \\
\cline { 2 - 5 } & 99 & 100 & 99.90 & 0.301 & 0.367 \\
$100 \mathrm{mmHg}$ & 99 & 100 & 99.95 & 0.218 & 0.218 \\
$120 \mathrm{mmHg}$ & 99 & 100 & 99.95 & & \\
$150 \mathrm{mmHg}$ & & & & & \\
\hline
\end{tabular}


Hendy Lesmana: Analisis Dampak Penggunaan Varian Tekanan Suction

Tabel 2 Nilai Saturasi Oksigen Sebelum dan Setelah Suctioning dengan Tekanan 100 mmHg, $120 \mathrm{mmHg}$ dan $150 \mathrm{mmHg}$ di Ruang NCCU 2013

\begin{tabular}{lccc}
\hline $\begin{array}{l}\text { Tindakan dan tekanan } \\
\text { suction }\end{array}$ & Mean + SD pre & Mean + SD post & p value \\
\hline \multicolumn{1}{c}{ Pre \& Post pd tekanan } & $99.90+0.301$ & $98.71+0.463$ & 0,0001 \\
$100 \mathrm{mmHg}$ & $99,95+0.218$ & $97.33+0.577$ & 0,0001 \\
$\begin{array}{l}\text { Pre \& Post pd tekanan } \\
120 \mathrm{mmHg}\end{array}$ & & \\
$\begin{array}{l}\text { Pre \& Post pd tekanan } \\
150 \mathrm{mmHg}\end{array}$ & $99,95+0.218$ & $96.05+0.669$ & 0,0001 \\
\hline
\end{tabular}

Tabel 3 Nilai Saturasi Oksigen Setelah Suctioning dengan Tekanan $100 \mathrm{mmHg}, 120 \mathrm{mmHg}$ dan 150 mmHg di Ruang NCCU 2013

\begin{tabular}{cccccc}
\hline Tekanan & \multicolumn{5}{c}{ Saturasi Oksigen (\%) } \\
\cline { 2 - 6 } Suction & Min & Max & Rata-Rata & SD & p Value \\
\hline $100 \mathrm{mmHg}$ & 98 & 99 & 98.71 & 0.463 & \\
$120 \mathrm{mmHg}$ & 96 & 98 & 97.33 & 0.577 & 0.0001 \\
$150 \mathrm{mmHg}$ & 95 & 97 & 96.05 & 0.669 & \\
\hline
\end{tabular}

Saturasi oksigen sebelum dilakukan suctioning pada tekanan $100 \mathrm{mmHg}, 120$ $\mathrm{mmHg}$ dan $150 \mathrm{mmHg}$ berkisar antara nilai minimal $99 \%$ dan nilai maksimal $100 \%$. Setelah dilakukan uji homogeneity dengan menggunakan levene test didapatkan nilai $p=0,367$, dengan demikian tidak terdapat perbedaan yang bermakna antara nilai saturasi oksigen sebelum dilakukan suctioning pada tekanan $100 \mathrm{mmHg}$, tekanan $120 \mathrm{mmHg}$ dan tekanan $150 \mathrm{mmHg}$. Setelah suctioning, saturasi oksigen responden dicatat dan dilakukan analisis dampak dari penerapan variasi $(100 \mathrm{mmHg}, 120 \mathrm{mmHg} \&$ $150 \mathrm{mmHg}$ ) tekanan suction yang digunakan (Tabel 2).

Saturasi oksigen setelah dilakukan suctioning pada tekanan $100 \mathrm{mmHg}, 120$ $\mathrm{mmHg}$ dan $150 \mathrm{mmHg}$ berbeda dan setelah dilakukan uji Friedman, didapatkan nilai $p=$ 0,0001 . Dapat disimpulkanterdapat perbedaan nilai saturasi oksigen setelah suctioning pada penggunaan tekanan $100 \mathrm{mmHg}, 120 \mathrm{mmHg}$ dan $150 \mathrm{mmHg}$, dimana semakin tinggi tekanan suction yang digunakan maka akan semakin banyak penurunan saturasi oksigen yang terjadi.

Gambaran nilai saturasi oksigen sebelum dan setelah suctioning pada penggunaan tekanan $100 \mathrm{mmHg}, 120 \mathrm{mmHg}$ dan 150 mmHg (Tabel 3).
Setelah suctioning, saturasi oksigen responden dicatat dan dilakukan analisis dampak dari penerapan variasi $(100 \mathrm{mmHg}$, $120 \mathrm{mmHg} \& 150 \mathrm{mmHg}$ ) tekanan suction yang digunakan (Tabel 3).

Saturasi oksigen sebelum dan setelah suctioning pada tekanan $100 \mathrm{mmHg}$ mengalami penurunan hingga $2 \%$. Pada tekanan $120 \mathrm{mmHg}$, saturasi oksigen sebelum dan setelah suctioning mengalami penurunan hingga $4 \%$ dan saturasi oksigen sebelum dan setelah suctioning pada tekanan $150 \mathrm{mmHg}$ mengalami penurunan hingga $5 \%$.

Dilanjutkan dengan uji post-hoc Wilcoxon dimana nilai $\mathrm{p}=0,0001$ pada ketiga tekanan, hal ini menunjukkan terdapat perbedaan saturasi oksigen sebelum dan setelah suctioning pada tekanan $100 \mathrm{mmHg}$, tekanan $120 \mathrm{mmHg}$ dan tekanan 150 $\mathrm{mmHg}$. Penerapan ketiga tekanan tersebut menyebabkan penurunan saturasi oksigen setelah suctioning dalam tingkatan yang berbeda-beda, dimana semakin besar tekanan maka akan semakin besar penurunan saturasi oskigen setelah suctioning.

\section{Pembahasan}

Pemberian terapi oksigen pada pasien cedera kepala berat merupakan hal yang penting guna 
Hendy Lesmana: Analisis Dampak Penggunaan Varian Tekanan Suction

mencegah terjadinya hipoksia otak yang akan menyebabkan kematian neuron yang dapat terjadi 5 menit awitan hipoksemia. Semua responden mendapatkan terapi oksigen, tetapi terdapat dua metode pemberian oksigen yang berbeda pada 21 responden tersebut, yaitu 16 responden mendapatkan terapi oksigen $T$ Piece dengan aliran $5 \mathrm{~L} /$ menit dan responden mendapatkan terapi oksigen menggunakan ventilator mode pressure support dengan FiO2 : $35 \%-75 \%$, PEEP : 5-8 $\mathrm{cmH}_{2} \mathrm{O}$ dan IPL : $6-10 \mathrm{cmH}_{2} \mathrm{O}$. Peneliti sulit untuk mendapatkan ketiga komponen tersebut dalam keadaan sama, sehingga ini merupakan suatu keterbatasan penelitian, walaupun setelah dilakukan uji Kruskal-Wallis pada dua metode pemberian oksigen tersebut (ventilator dan $\mathrm{T}$ Piece) terhadap saturasi oksigen setelah suctioning, didapatkan $\mathrm{p}>$ 0,05 dimana tidak terdapat perbedaan yang bermakna saturasi oksigen setelah suctioning pada pasien yang mendapatkan terapi oksigen $\mathrm{T}$ Piece dan Ventilator dengan penggunaan tekanan suction $100 \mathrm{mmHg}, 120 \mathrm{mmHg}$ dan $150 \mathrm{mmHg}$.

Teknik suction yang digunakan pada penelitian ini adalah open suction, dimana teknik open suction pada pasien yang terpasang ventilator ketika sambungan antara ETT dengan selang Y pada ventilator terputus, menyebabkan tekanan jalan nafas menurun mendekati tekanan atmosfir sebelum suctioning berlangsung sehingga tidak terdapat perbedaan tekanan jalan nafas pada pasien yang terpasang ventilator dan tidak terpasang ventilator bila menggunakan teknik open suction (Almgren, Wickerts, Heinonen, \& Hogman, 2003).

Nilai saturasi oksigen sebelum dilakukan suction (setelah tindakan hiperoksigenasi) pada tekanan $100 \mathrm{mmHg}$, tekanan $120 \mathrm{mmHg}$ dan tekanan $150 \mathrm{mmHg}$ terbanyak pada nilai $100 \%$, hal ini disebabkan karena adanya tindakan hiperoksigenasi yang dilakukan selama 2 menit. Tindakan hiperoksigenasi dilakukan dengan cara memberikan oksigen $100 \%$ melalui pemberian $\mathrm{FiO} 2100 \%$ (pada pasien yang terpasang ventilator) atau dengan pemberian oksigen menggunakan bag valve mask dengan reservoir pada aliran 10 liter/menit (pada pasien yang terpasang $\mathrm{T}$ Piece). Saturasi oksigen sebelum dilakukan suctioning (setelah tindakan hiperoksigenasi) pada tekanan $100 \mathrm{mmHg}$, tekanan 120 $\mathrm{mmHg}$ dan tekanan $150 \mathrm{mmHg}$ tidak menunjukkan perbedaan yang bermakna, hal ini terbukti setelah dilakukan levene test yang menunjukkan nilai $p=0,367$. Penelitian yang dilakukan oleh Smith et al. (1987) yang menyatakan tidak terdapat perbedaan yang bermakna pada dua protokol hiperoksigenasi sebelum dilakukan suction antara pemberian FiO2 $100 \%$ pada ventilator dan pemberian 10 liter/menit dengan menggunakan bag valve mask dengan reservoir $(\mathrm{p}>0,05)$ pada pasien yang terpasang ventilator, dimana kedua protokol tersebut dapat meningkatkan saturasi hingga $100 \%$ yang dapat mencegah hipoksemia pasca suctioning (Hahn. , 2010; American Association for Respiratory Care, 2010).

Penelitian yang dilakukan oleh $\mathrm{Oh}$ dan Seo (2003), tindakan hiperoksigenasi sebelum suctioning dapat menurunkan angka kejadian hipoksemia akibat suction sebesar $32 \%$, sedangkan tindakan hiperoksigenasi yang dilakukan sebelum dan setelah suctioning dapat menurunkan angka kejadian hipoksemia akibat dari suctioning sebesar 49 $\%$. Prosedur hiperoksigenasi pada penelitian ini dilakukan sebelum dan setelah suctioning guna mencegah terjadinya hipoksemia akibat dari suctioning tersebut.

Ukuran kateter suction yang digunakan pada penelitian ini berdasarkan pada rumus : $\mathrm{Fr}=($ Ukuran ETT -1$) \times 2$, hal ini berdasarkan pada penelitian Hahn (2010), dimana rumus yang digunakan tersebut menghasilkan ukuran kateter suction kurang dari setengah diameter ETT dan mempunyai kemampuan evakuasi sekresi lebih baik bila dibandingkan dengan penerapan rumus yang lain $(\mathrm{Fr}=$ $<$ Ukuran ETT-2> x 2).

Nilai saturasi oksigen setelah suctioning pada tekanan $100 \mathrm{mmHg}$ menunjukkan nilai minimal $98 \%$, pada tekanan $120 \mathrm{mmHg}$ dengan nilai minimal $96 \%$ dan pada tekanan $150 \mathrm{mmHg}$ menunjukkan nilai minimal $95 \%$. Terlihat perbedaan nilai saturasi oksigen pada penggunaan ketiga tekanan suction tersebut, hal ini hal ini didukung dengan hasil uji Friedman $p=0,0001$. Selain itu pula terlihat semakin besar penggunaan tekanan suction yang digunakan pada saat suctioning maka 
akan semakin besar terjadi penurunan nilai saturasi oksigen, hal ini tergambar pada nilai rata-rata saturasi oksigen setelah suctioning pada masing-masing tekanan suction yg digunakan.

Nilai saturasi oksigen sebelum dan setelah suctioning pada tekanan $100 \mathrm{mmHg}$ mengalami penurunan hingga $2 \%$, pada tekanan $120 \mathrm{mmHg}$ mengalami penurunan hingga $4 \%$ dan pada penggunaan tekanan $150 \mathrm{mmHg}$ mengalami penurunan hingga $5 \%$. Secara keseluruhan dapat disimpulkan bahwa terdapat perbedaan nilai saturasi oksigen sebelum dan setelah suctioning pada penggunaan tekanan $100 \mathrm{mmHg}, 120 \mathrm{mmHg}$ dan $150 \mathrm{mmHg}$, hal ini didukung dengan hasil uji Wilcoxon untuk ketiga tekanan adalah $p$ $=0,0001$. Secara umum penggunaan ketiga tekanan tersebut tidak menyebabkan nilai saturasi jatuh di bawah normal $(\mathrm{SaO} 2 \geq 95$ $\%)$.

Penelitian yang dilakukan oleh Cereda et al. (2001), pada penggunaan tekanan suction $100 \mathrm{mmHg}$ akan menyebabkan kehilangan volume udara pada paru hingga $1200 \mathrm{ml}$ terutama dengan menggunakan teknik open suction, demikian pula dengan penelitian yang dilakukan oleh Fernandez et al. (2004), bahwa penggunaan tekanan suction 150 $\mathrm{mmHg}$ dapat menyebabkan kehilangan udara paru sebesar 1,281 +656 ml. Semakin besar tekanan suction maka semakin besar jumlah udara yang terisap dari paru-paru, hal ini akan berdampak pada penurunan jumlah oksigen yang akan berdifusi dari alveoli ke kapiler paru dan berikatan dengan hemoglobin yang kemudian akan terlihat pada penurunan nilai saturasi oksigen.

Penerapan tekanan suction $100 \mathrm{mmHg}$ dapat dilakukan pada setiap suctioning terutama pada pasien cedera kepala berat yang nilai saturasinya 97-100\%, karena tekanan suction $100 \mathrm{mmHg}$ hanya dapat menurunkan saturasi oksigen sebanyak $2 \%$. Penerapan tekanan suction $120 \mathrm{mmHg}$ dapat digunakan pada pasien cedera kepala dengan saturasi oksigen $99-100 \%$, karena pada penggunaan tekanan ini dapat menurunkan saturasi oksigen hingga $4 \%$ dan tekanan suction $150 \mathrm{mmHg}$ dapat diterapkan pada saturasi oksigen $100 \%$, karena pada penggunaan tekanan ini dapat menurunkan saturasi oksigen hingga $5 \%$. Bila terdapat pasien cedera kepala yang mempunyai nilai saturasi oksigen $<95 \%$ walaupun telah dilakukan tindakan hiperoksigenasi dan harus dilakukan suctioning karena terdapat mukus pada saluran nafas, maka dapat digunakan tekanan suction $100 \mathrm{mmHg}$ guna mengevakuasi sekret yang ada di saluran nafas juga risiko penurunan saturasi oksigen yang terjadi akibat suctioning dapat seminimal mungkin.

Penggunaan tekanan suction $100 \mathrm{mmHg}$, $120 \mathrm{mmHg}$ dan $150 \mathrm{mmHg}$, berdampak pula pada kemampuan evakuasi mukus pada jalan nafas. Hal ini terlihat pada jumlah fase suction yang dilakukan dalam satu periode suction. Penggunaan tekanan suction 100 $\mathrm{mmHg}$, jumlah fase suction yang terbanyak adalah 3-4 kali $(66,7 \%)$ dalam satu periode evakuasi mukus. Pada penggunaan tekanan suction $120 \mathrm{mmHg}$, jumlah fase suction yang terbanyak adalah 3-4 kali $(61,9 \%)$ dalam satu periode evakuasi mukus. Penggunaan tekanan suction $150 \mathrm{mmHg}$, jumlah fase suction yang terbanyak adalah 1-2 kali $(90,5 \%)$ dalam satu periode evakuasi mukus. Disini terlihat bahwa semakin besar tekanan suction yang digunakan maka semakin rendah jumlah fase suction yang dibutuhkan dalam satu periode evakuasi mukus. Hal ini didukung dengan hasil penelitian yang dilakukan oleh Lasocki et al. (2006), yang mana penggunaan tekanan negatif suction yang semakin besar akan meningkatkan kemampuan pengangkutan (removal) mukus dari jalan nafas tetapi terjadi juga peningkatan kehilangan volume paru terutama pada teknik open suction $(\mathrm{p}=$ $0,02)$.

Penelitian yang dilakukan oleh Day, Farnell, Haynes, Wainwright, dan Bernett (2002), memberikan rekomendasi sebaiknya jumlah fase dalam satu periode evakuasi mukus adalah tidak lebih dari 3 kali karena akan potensial meningkatkan terjadi komplikasi dari suction diantaranya trauma pada mukosa jalan nafas. Demikian pula dengan Glass dan Grap (1995), menganjurkan untuk tidak melakukan lebih dari tiga fase suction dalam satu episode suctioning karena dapat menyebabkan cedera pada saluran nafas.

Perubahan tanda-tanda vital sebelum suctioning merupakan salah satu indikasi dari 
Hendy Lesmana: Analisis Dampak Penggunaan Varian Tekanan Suction

adanya mukus pada saluran nafas, dimana saat mukus menutup sebagian saluran nafas maka terjadi penurunan tidal volume yang berdampak pada penurunan saturasi oksigen, sehingga tubuh melakukan kompensasi dengan peningkatan frekuensi pernafasan dan peningkatan denyut jantung (Schell \& Puntilo, 2006; Potter \& Perry, 2010). Responden pada penelitian ini menunjukkan tanda-tanda vital dalam batas normal, tetapi pencatatan menunjukkan peningkatan tanda-tanda vital (terutama denyut jantung dan frekuensi pernafasan) akibat adanya sekresi pada saluran nafas (indikasi suction) yang menyebabkan rangsangan batuk dan penurunan saturasi oksigen.

Penelitian ini, yang mana pasien cedera kepala yang mendapatkan suctioning pada tekanan $100 \mathrm{mmHg}, 120 \mathrm{mmHg}$ maupun pada tekanan suction $150 \mathrm{mmHg}$ juga mengalami perubahan pada tanda-tanda vital. Perubahan yang terjadi terutama pada tekanan darah sistolik, peningkatan tekanan darah diastolik, peningkatan tekanan arteri rata-rata (Mean Arterial Pressure) dan peningkatan frekuensi denyut jantung dan frekuensi pernafasan.

Perubahan pada tanda-tanda vital ini disebabkan karena ketika kateter suction yang menyentuh karina (reseptor batuk), sehingga menstimulasi pasien untuk batuk. Ketika proses batuk terjadi, maka terjadi inspirasi dalam secara cepat dengan demikian terjadi peningkatkan tekanan intratorakal, otot abdomen kontraksi dan kontraksi otot interkostalis internus, menyebabkan diafragma naik dan tekanan paru-paru meningkat (sampai dengan 100 $\mathrm{mmHg}$ ) dan kemudian terjadi pengeluaran udara (ekspirasi) yang cepat dan keras (kecepatan udara yang diciptakan 16.000$24.000 \mathrm{~cm} /$ menit). Peningkatan frekuensi pernafasan akibat dari ketidakteraturan pada pola pernafasan (inspirasi dan ekspirasi yg cepat) karena adanya respon batuk (akibat stimulus reseptor batuk oleh kateter suction yg menyentuh karina). Peningkatan tekanan darah sistolik akibat dari peningkatan afterload yang diakibatkan dari peningkatan tekanan intraabdomen yang menstimulasi untuk meningkatkan stroke volume guna menjamin cardiac output yang adekuat. Peningkatan tekanan darah diastolik akibat dari meningkatnya tekanan intratorakal yang menyebabkan hambatan pada fase pengisian atrium (peningkatan tekanan intraatrium), sehingga terjadi peningkatan tekanan preload. Peningkatan tekanan darah sistolik dan diastolik mengakibatkan meningkatnya tekanan arteri rata-rata (MAP) (Guyton \& Hall, 2010; Almgren, Wickerts, Heinonen, \& Hogman, 2003).

Peningkatan tanda-tanda vital ini telah diidetifikasi pada penelitian yang dilakukan oleh lucchini et al. (2012), setelah suctioning terjadi peningkatan denyut jantung sebanyak $2,93 \%(\mathrm{p}=0,02)$. Demikian pula dengan penelitian yang dilakukan oleh Stone et al. (1998), dimana terjadi peningkatan tekanan arteri rata-rata, cardiac output dan tekanan arteri pulmonal setelah suctioning $(\mathrm{p}=$ 0,0001).

American Association for Respiratory Care (2010), menganjurkanuntuk selalu melakukan pengaturan tekanan sebelum suctioning dilakukan dengan cara menutup ujung selang yang menghubungkan kateter suction dengan tempat penampung mukus kemudian tekanan yang dianjurkan $(100 \mathrm{mmHg}-150$ $\mathrm{mmHg}$ ) diatur dengan memutar pengatur tekanan (vacum regulator) yg terdapat pada alat suction control. Penggunaan tekanan suction yang berlebihan ( $>150 \mathrm{mmHg}$ ) dapat menyebabkan penurunan saturasi oksigen, trauma pada jalan nafas hingga menyebabkan kolaps alveoli. Penelitian yang dilakukan oleh Leur, Zwapeling, Loef, dan Schans (2003), menyatakan penggunaan tekanan suction 200-400 $\mathrm{mmHg}$ dapat menyebabkan kerusakan mukosa jalan nafas, memperpanjang hari rawat hingga berakibat fatal yakni menimbulkan kematian.

\section{Simpulan}

Terdapat perbedaan yang bermakna nilai saturasi oksigen setelah suction dengan tekanan $100 \mathrm{mmHg}, 120 \mathrm{mmHg}$ dan 150 $\mathrm{mmHg}$. Penggunaan tekanan suction 100 mmHg terbukti menyebabkan penurunan saturasi oskigen yang paling minimal bila dibandingkan dengan tekanan $120 \mathrm{mmHg}$ dan $150 \mathrm{mmHg}$.

Ketiga penggunaan tekanan suction (100 
$\mathrm{mmHg}, 120 \mathrm{mmHg}$ dan $150 \mathrm{mmHg}$ ) tidak menyebabkan penurunan saturasi oksigen $>5 \%$, sehingga dapat digunakan pada pasien cedera kepala yang memiliki nilai saturasi oksigen $100 \%$ (setelah tindakan hiperoksigenasi). Penggunaan ketiga tekanan tersebut suction memertimbangkan kondisi pasien terutama nilai saturasi oksigen dan jumlah produksi mukus.

Penggunaan tekanan suction dilahan praktik dapat diterapkan berdasarkan hasil penelitian yang menunjukkan tekanan suction $100 \mathrm{mmHg}$ dapat menurunkan saturasi oksigen yang minimal, sehingga lebih tepat digunakan pada pasien cedera kepala yang membutuhkan suctioning dengan saturasi oksigen setelah hiperoksigenasi $<95 \%$.

Sebaiknya lakukan tindakan hiperoksigenasi selama 1-3 menit sebelum dan setelah suctioning guna mencegah terjadinya penurunan saturasi oksigen kurang dari $95 \%$. Satu fase suctioning pada pasien dewasa tidak boleh melebihi dari 15 detik karena akan menyebabkan penurunan saturasi pasien kurang dari $95 \%$.

Perlu dilakukan penelitian lebih lanjut mengenai hubungan PEEP dan tekanan suction pada teknik close suction terhadap saturasi oksigen pada pasien yang terpasang ventilator.

\section{Daftar Pustaka}

Almgren, B., Wickerts, CJ., Heinonen, E., \& Hogman, M. (2004). Side Effects of Endotracheal Suction in Pressure and Volume Controlled Ventilation. Chestjournal. org. Melalui http://www.google.co.id. chestjournal.chestidiakses pada 1/02/13.

American Association for Respiratory Care. (2010). Endotracheal Suctioning of Mechanically Ventilated Patients With Artificial Airways 2010. AARC Clinical Practice Guidelines. Melalui http://www. apicwv.org/docs/1.pdf!. Diakses pada tanggal $1 / 02 / 13$.

Basford, L \& Slevin, O. (2006). Teori dan Praktik Keperawatan Pendekatan Integral Pada Asuhan Pasien. Jakarta: PT. EGC.
Basuki, A \& Dian, S. (2009). Kedaruratan Neurologi. Bandung. Ilmu Penyakit Saraf FK UNPAD.

Berman, A. Snyder, S. Kozier, B. \& Erb, G. (2009). Buku Ajar Praktik Keperawatan Klinis, Edisi 5. Terjemahan Eny meiliya, Esty Wahyuningsih, Devi Yulianti, \& Fruriolina Ariani. Jakarta: PT. EGC.

Cereda, et al. (2001). Closed System Endotracheal Suctioning Maintains Lung Volume During Volume Controlled Mechanical Ventilation. Intensive Care Medicine. Volume 27. Melalui www.ncbi. nlm.nih.gov/pubmed/11398690". Diakses pada tanggal $1 / 02 / 13$.

Day, T., Farnell, S., Haynes, S., Wainwright, S., \& Bernett, J.W. (2002). Tracheal Suctioning : an Exploration of Nurses' Knowledge and Competence In Acute and High Depedency Ward Areas. Melalui http:// web.ebscohost.com/ehost/19. Diakses pada tanggal 1/02/13.

Fernandez, et al. (2004). Changes in Lung Volume With Threesystems of Endotracheal Suctioning With and Without Preoxygenation in Patients With Mild to Moderate Lung Failure. Intensive Care Medicine Volume 30. Melalui www.ncbi.nlm.nih.gov/ pubmed/15480564. Diakses pada tanggal $1 / 02 / 13$.

Glass, C.A. \& Grap, M.J. (1995). Ten Tips for Safer Suctioning. Advanced Journal of Nursing Volume 5. Melalui www.ncbi.nlm. nih.gov/pubmed/7733173|. Diakses pada tanggal $1 / 02 / 13$.

Guyton, A.C. \& Hall, J.E. 2010. Buku Ajar Fisiologi Kedokteran. Terjemahan Irawati Setyawan, LMA Ken Ariata Tengadi dan Alex Santoso, Edisi 9. Jakarta: PT. EGC.

Hahn, M. (2010). 10 Consideration for Endotracheal Suctioning. rtmagazine.com. Melalui http://web.ebscohost.com/ehost/ pdfviewer/19. Diakses pada tanggal 1/2/13.

Hudak, C.M. \& Gallo, B.M. (2010). Keperawatan Kritis Pendekatan Holistik, 
Hendy Lesmana: Analisis Dampak Penggunaan Varian Tekanan Suction

Vol. 1. Terjemahan Allenidekania, Betty Susanto, Teresa, Yasmin, \& Monica Ester. Jakarta: PT. EGC.

Hudak, C.M. \& Gallo, B.M. (2010). Keperawatan Kritis Pendekatan Holistik, Vol. 2. Terjemahan Allenidekania, Betty Susanto, Teresa, Yasmin, \& Monica Ester. Jakarta: PT. EGC.

Kelleher, S. \& Andrews, T. (2006). An Observational Study On The Open-System Endotracheal Suctioning Practices Of Critical Care Nurses. Melalui http://web. ebscohost.com/ehost/pdfviewer/19. Diakses pada tanggal 1/02/13.

Kozier, B., Erb, G., Berman, A., \& Snyder, S.J. (2011). Buku Ajar Fundamental Keperawatan, Konsep, Proses dan Praktik. Jakarta: PT. EGC.

Lasocki, S., et al. (2006). Open and Closed-circuit Endotracheal Suctioning in Acut Lung Injury. Anesthesiology Volume 104. Melalui http://www.google.co.id/ url2FDocumentation. Diakses pada tanggal 1/02/13.

Leur, JP., Zwavelng, JH., Loef, BG., \& Schans, CP. (2003). Endotracheal Suctioning Versus Minimally Invasive Airway Suctioning in Intubated Patients : A Prospective Randomised Controlled Trial. Melalui www.ncbi.nlm.nih.gov/pubmed/12577156|. Diakses pada tanggal 1/02/13.

Lucchini, A., et al. (2011). Tracheal Secretion Management In The Mechanically Ventilated Patient : Comparison Of Standard Assessment And An Acoustic Secretion Detector. Melalui http://web.ebscohost.com/ ehost/pdfviewer/19. Diakses pada tanggal 1/02/13.
Muttaqin, A. (2008). Buku Ajar Asuhan Keperawatan Klien Dengan Gangguan Sistem Persarafan. Jakarta: PT. Salemba Medika.

Oh, H. \& Seo, W. (2003). A Meta-analysis of The Effects of Various Interventions in Preventing Endotracheal Suction Induced Hypoxemia. Journal of Clinical Nursing, Volume 12. Melalui http://web.ebscohost. com/ehost/pdfviewer/28. Diakses pada tanggal 01/02/2013.

Potter, P.A. \& Perry, A.G. (2010). Buku Ajar Fundamental Keperawatan. Buku 3. Edisi 7. Terjemahan Renata Komalasari, Dian Evriyani, Enie Novieastari, Alfrina Hany dan Sari Kurnianingsih. Jakarta: Salemba Medika.

Schell, H.M. \& Puntilo, K.A. (2006). Nursing Secrets Series Critical Care Nursing Secrets. Second Edition. Philadelphia: Mosby Elsevier.

Stone, et al. (1998). The Effect Of Repeated Endotracheal Suctioning on Arterial Blood Pressure. Applied Nursing Research. Volume 4. Melalui www.sciencedirect.com/science/ article/pii/S0897189705800898. Diakses pada tanggal $1 / 02 / 13$.

Wainwright, S. \& Gould, D. (1996). Endotracheal Suctioning : an Example of The Problems of Relevance and Rigour In Clinical Research. Melalui http://web. ebscohost.com/ehost/pdfviewer/19. Diakses pada tanggal 1/02/13.

Woodward, S \& Mestecky, A.M. (2011). Neuroscience Nursing Evidance-Based Practice. United Kingdom: Wiley-Blackwell. 